\section{DAME MARGARET SEWARD 1935-2021}

BDJ Team is sad to report the death of Dame Margaret Seward on 22 July 2021. Dame Margaret was the first female resident dental house surgeon at the London Hospital, Editor of the $B D J$ from 1979-1992 and the second female President of the British Dental Association (BDA) in 1993. She was the first female President of the General Dental Council (GDC) (19941999). An obituary has been published in the BDJ: https://www.nature.com/articles/ s41415-021-3327-y.

Dame Margaret was very supportive of BDJ Team's predecessor, Vital (for the whole dental team), which was published from 2003-2013 by the BDJ Portfolio. In 2008, upon a re-launch, she wrote to the letters page: 'I just saw the latest issue of Vital and the impressive new website and wanted to say "congratulations!" What a lot of work has gone into the new look all worth the effort and such interesting articles as well'.

The British Association of Dental Nurses (BADN) was also saddened to hear of Dame Margaret's death; she was a great supporter of the dental team, and of

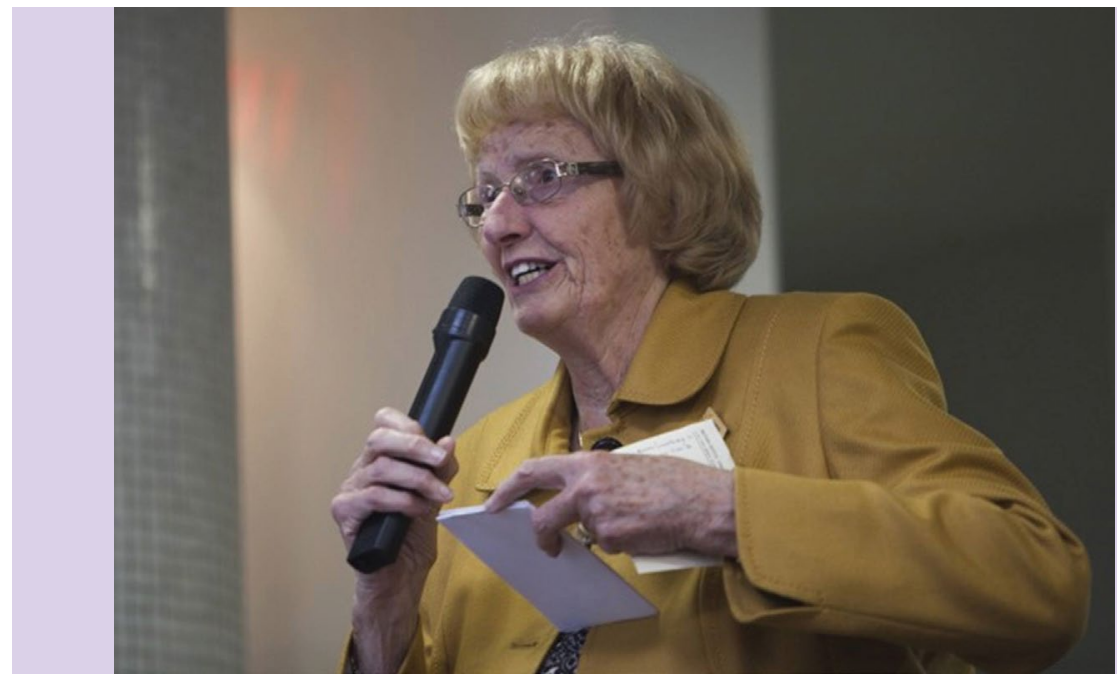

dental nurses. As President of the GDC she supported the campaign for registration of the whole dental team.

The BADN said: 'Dame Margaret was an inspiration to those of us who struggled to be heard in a predominantly male environment; a great supporter of dental nurses and a formidable ally to BADN ... always dignified, gracious ... and with a wicked sense of humour! She will be greatly missed'.

Dame Margaret also set up the Dental Technicians Education and Training Advisory Board (DTETAB), in support of under recognised UK dental technicians. Her foresight was instrumental in developing the organisation that represents dental technicians today as the Dental Technologists Association.

Tony Griffin, former President and Chair of DTA said: 'Dame Margaret continually strove to improve UK dentistry and in that to support the dental technician's role within the oral health care team. She inspired and encouraged all those in dental technology and clinical dental technology to develop their profession to meet the future needs of our communities'.

\section{TOOTHBRUSHING CLUBS} CONTINUE IN CORNWALL

Over 420 pupils at Carclaze Community Primary School will continue improving their oral health after Imerys Minerals and West Carclaze Garden Village renewed their commitment for the third year running to Brighter Smiles - Cornwall's oral health campaign.

Their donations reflect both companies' commitment to reversing the continuing trend of avoidable tooth extractions from children in Cornwall.

This support has enabled the Brighter Smiles team to once again set up toothbrushing clubs in the reception classes and deliver oral health education to all the schools' pupils with home education packs for all to encourage continued good practice at home with all the family. Although currently paused due to the pandemic, it will also enable the team to apply fluoride varnishing to the teeth

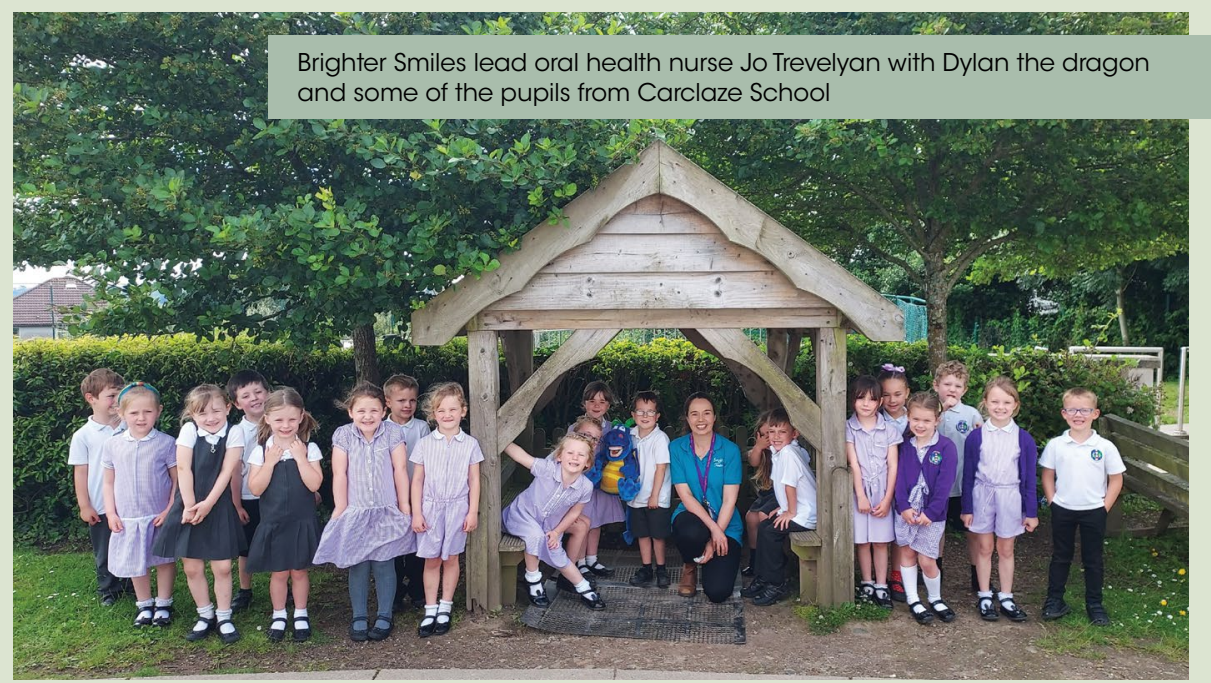

of reception and year 1 pupils, once Public Health England give the go-ahead for this to resume.

Simon Pollard, Head Teacher at Carclaze Community Primary School said 'The pupils look forward to seeing the team and their dragon, and really engage with the fun oral health activities.
In addition to Cornwall Council, Imerys and West Carclaze Garden Village, Brighter Smiles is supported by other local and national organisations. In previous years over 80 schools, nurseries and family hubs and 4,500 children have regularly engaged in the programme but with 280 schools in Cornwall there is still much more to do. 